\title{
Brazilian Protocol for Sexually Transmitted Infections 2020: sexual violence
}

\author{
Maria Luiza Bezerra Menezes[1], Maria Alix Leite Araújo ${ }^{[2]}$, Adriano Santiago Dias dos Santos ${ }^{[3]}$, \\ Elucir Gir ${ }^{[4]}$ and Ximena Pamela Díaz Bermúdez ${ }^{[5]}$
}

\author{
[1]. Universidade de Pernambuco, Departamento Materno-Infantil, Recife, PE, Brasil. \\ [2]. Universidade de Fortaleza - UNIFOR, Programa de Pós-Graduação em Saúde Coletiva, Fortaleza, CE, Brasil. \\ [3]. Ministério da Saúde, Secretaria de Vigilância em Saúde, Brasília, DF, Brasil. \\ [4]. Universidade de São Paulo, Escola de Enfermagem de Ribeirão Preto, Ribeirão Preto, SP, Brasil. \\ [5]. Universidade de Brasília, Departamento de Saúde Coletiva, Brasília, DF, Brasil.
}

\begin{abstract}
This article addresses sexual violence, as part of the Clinical Protocol and Therapeutic Guidelines for Comprehensive Care for People with Sexually Transmitted Infections, published by the Brazilian Ministry of Health. Guidance is provided in programmatic and operational management, focusing on the service network for people in situation of sexual violence, recommendations to health staff about pregnancy and viral and non-viral sexually transmitted infections prophylactic measures, in addition to surveillance action strategies. Sexual violence is an encompassing issue that includes wider areas than the health field. It involves conceptual and programmatic challenges for health staff, at the forefront of care for affected people and also to the implementation of prevention strategies addressed to the whole society.
\end{abstract}

Keywords: Sexual offenses. Intimate partner violence. Sexually transmitted diseases. Clinical protocols.

Highlighted excerpt: Sexual violence is one of the principal forms of human rights violation, affecting the right to life, health, and bodily integrity.

\section{FOREWORD}

This article addresses sexual violence, as part of the Clinical Protocol and Therapeutic Guidelines for Comprehensive Care for People with Sexually Transmitted Infections (STI), in addition to the PDCT on Post-Exposure Prophylaxis for Risk of HIV infections, STI and Viral Hepatitis, and the PDCT on HIV Infections Management in Children and Adolescents, published by the Brazilian Ministry of Health. The PDCT for Comprehensive Care for People with STI was approved by the National Committee for the Incorporation of Technologies (CONITEC) in the Brazilian National Health System $(\mathrm{SUS})^{1}$ and updated by the group of specialists in STI in 2020.

\footnotetext{
Corresponding author: Adriano Santiago Dias dos Santos.

e-mail: adriano.santos@aids.gov.br

(D) https://orcid.org/0000-0001-8514-1862

Received 01 February 2021

Accepted 10 March 2021
}

\section{INTRODUCTION}

Sexual violence is defined as "any sexual act, attempt to obtain a sexual act, unwanted sexual comments or advances, or acts to traffic, or otherwise directed, against a person's sexuality using coercion, by any person regardless of their relationship to the victim, in any setting, including but not limited to home and work"2.

Sexual violence is an intrinsic issue in several contemporary societies, often neglected. It can affect both sexes and all age groups, including severe physical consequences and emotional trauma for both victims and their families ${ }^{3}$. It is a multidimensional phenomenon, present in every social class, race, ethnic group, gender relation, and sexual orientation. It is one of the principal forms of human rights violation, affecting the right to life, health, and physical integrity ${ }^{4-5}$.

Facing sexual violence requires the participation of health, education, work, law enforcement, justice, and human rights bodies. It needs intersectoral public policies and integrated actions by the State and society in general. The role of respecting diversity and gender identities is highlighted, assuring access to rights in all areas and privileging the health of those affected ${ }^{6-7}$. 
One of the most serious - and most common - types of sexual violence is rape, defined as "physically forced or otherwise coerced penetration - even if slight - of the vulva or anus, using a penis, other body parts or an object" 2 . Rape crime is defined in the Brazilian Criminal Code as the "act of embarrassing someone, through violence or serious threat, to have carnal conjunction or to practice or allow another libidinous act to be practiced"8.

Sexual violence has achieved notoriety. However, it is necessary to propose research agendas that contribute to scientific evidence in this field ${ }^{6,9,10}$. Records indicate that female individuals are the most affected, representing more than $80 \%$ of sexual violence victims ${ }^{6}$. In the period from 2011 to $2018,1,282,045$ cases of violence against women were reported ${ }^{9}$.

Although scientific evidences point out that sexual violence occurs primarily among women, it also happens against men. For instance, a study that analyzed data on rape from 2017 to 2018 found that children aged from five to nine years old, were the most affected age group in males, representing around a quarter of the cases and the victimization peak occurred within boys aged seven years old ${ }^{6}$. Not only should the report of these events and their physical and psychosocial consequences be improved, but also it is suggested to develop studies to fill this empirical vacuum ${ }^{11}$. It can be observed that, although the constitution of masculinities predispose men not to recognize this type of violence, in the context of armed conflict, displacement, and migration sexual violence affecting men can occur in a higher incidence ${ }^{12-14}$.

Available data show that only $7.5 \%$ of the occurrence of sexual violence in 2019 in Brazil were reported to police authorities ${ }^{15}$; regarding rape, more than $60 \%$ of them are committed against vulnerable people, that is, people under 14 years old, considered legally unable to consent sexual intercourse. The same category refers to people unable to resist, regardless of their age, as someone under the effect of drugs, sickness, or dissability (Act No. 12,015, of August 7, 2009). It also shows the predominance of male aggressors in more than $80 \%$ of the cases ${ }^{15}$.

It is necessary to consider that sexual violence also affects transgender people, a social group of high vulnerability to violence and to sexually transmitted infections. Systematic review, based on 74 studies with this population, developed in Brazil and other countries, revealed that stigma and prejudice are related to gender identity and sexual orientation, expressed in the high prevalence of physical and sexual violence events against this social group ${ }^{16}$.

One of the sexual violence consequences is the possibility of STI transmission ${ }^{17}$, which causes fear and anxiety in victims, especially when it is related to the human immunodeficiency virus (HIV). For this reason, immediate assistance should be offered to the victim through clinical and laboratory care, post-exposure prophylaxis (PEP) on risk for HIV infection, viral hepatitis and non-viral STI (gonorrhea, syphilis, chlamydia infection, trichomonas infections, and cancer), psychological and social care, unintended pregnancy prevention, in addition to adequate guidance on medical procedures and legal rights ${ }^{18}$.

A cross-sectional study that estimated the occurrence of pregnancy and STI due to sexual violence in the state of Santa
Catarina between the years 2008 and 2013 identified that, 7,6\% became pregnant, and 3,5\% were affected by some $\mathrm{STI}^{17}$. The risk for such infections depends on the type of exposure (vaginal, anal, or oral), number of aggressors, exposure recurrence, presence of genital trauma, the victim's age, and their susceptibility (hymenal condition and previous presence of other STI) ${ }^{17}$.

Sexual violence, when committed by intimate partner, entails affective feelings which makes it more challenging to deal with. This is related to social, cultural, and economic context, such as naturalized values, ideologies, and norms ${ }^{3,19}$. Structured relationships, gender inequities, individual conditions and the social representation of violence give meaning to this phenomenon ${ }^{20}$.

For such reasons, in addition to full knowledge on and implementation of therapeutic guidelines by health professionals, sexual violence victims must have assured access to the different support services for trauma recovery and healing process, with a comprehensive approach including physical, mental, and sexual health ${ }^{21}$.

\section{SEXUALLY TRANSMITTED INFECTION PROPHYLAXIS IN SEXUAL VIOLENCE SITUATIONS}

Care within sexual violence events is urgent and access and support must be assured, recognizing key and priority populations' specificities. Such service must be offered in an appropriate place, with privacy assurance and no moral judgments. An initial assessment of the patient must include a comprehensive approach of the violent event and the pertinence of a prophylaxis prescription ${ }^{22,23}$.

Immediate beginning of non-viral STI prophylaxis is recommended in all sexual violence cases, whenever possible ${ }^{22}$ and among pregnant women prophylactic administration is recommended at any gestational age ${ }^{18}$. The prophylactic regimen can be postponed depending on conditions that hinder adherence, such as people under extreme physical or emotional fragility. It can be avoided in cases of gastrointestinal intolerance to medications. Non-viral STI prophylactic regime in sexual violence situations is shown in Figure 1.

Post-exposure prophylaxis (PEP) at risk for HIV infection (PEP), viral hepatitis, and other STIs is a prevention strategy offered by the Brazilian National Health System (SUS). It consists of adopting drugs to reduce the risk of acquiring such infections ${ }^{18,24}$. PEP for $\mathrm{HIV}$ in Brazil is provided as one of the combine prevention strategies available for expanding intervention to prevent new HIV infections ${ }^{18}$. Combined prevention unites conjugates different actions and includes the combination of biomedical, behavioral, and structural interventions that can be applied in a individual or collective scope ${ }^{25}$. PEP for HIV prescribes antiretrovirals treatment during a period of 28 days and should be started no later than 72 hours after exposure. The preferred schema must include combinations of three or four antiretrovirals. It must be composed of two nucleoside reverse transcriptase inhibitors, preferably co-formulated, associated with another class, usually integrase inhibitors, preferably dolutegravir, or protease inhibitors with ritonavir, as a pharmaceutic adjuvant ${ }^{18,26,27}$. Presentation and dosages of preferred antiretrovirals recommended in Brazil for PEP, are shown in Figure $2^{18}$. 


\begin{tabular}{|c|c|c|c|}
\hline \multirow[b]{2}{*}{ Sexually transmitted infections } & \multirow[b]{2}{*}{ Medication } & \multicolumn{2}{|c|}{ Dosage } \\
\hline & & $\begin{array}{l}\text { Adults and adolescents with more } \\
\text { than } 45 \mathrm{~kg} \text {, including pregnant } \\
\text { women }\end{array}$ & $\begin{array}{c}\text { Children and adolescents with } \\
\text { less than } 45 \mathrm{~kg}\end{array}$ \\
\hline Syphilis & Benzathine benzylpenicillin & $\begin{array}{l}2.4 \text { million international units (IU), } \\
\text { intramuscular (IM), single dose } \\
\text { (divided in two injections) }\end{array}$ & $\begin{array}{l}50,000 \mathrm{IU} / \mathrm{kg}, \mathrm{IM}, \text { single dose } \\
\text { (maximum total dose: } 2.4 \text { million IU) }\end{array}$ \\
\hline Gonorrhea & Ceftriaxone + azithromycin & $\begin{array}{l}\text { Ceftriaxone } 500 \mathrm{mg}, 1 \text { ampoule, } \\
\text { IM, single dose plus azithromycin } \\
500 \mathrm{mg}, 2 \text { pills, oral route }(\mathrm{OR}) \text {, single } \\
\text { dose (total dose: } 1 \mathrm{~g} \text { ) }\end{array}$ & $125 \mathrm{mg}, \mathrm{IM}$, single dose \\
\hline Chlamydia infection & Azithromycin & $\begin{array}{l}500 \mathrm{mg} \text {, two pills, OR, single dose } \\
\text { (total dose: } 1 \mathrm{~g} \text { ) }\end{array}$ & $\begin{array}{l}20 \mathrm{mg} / \mathrm{kg} \text { weight, OR, single dose } \\
\text { (maximum total dose: } 1 \mathrm{~g} \text { ) }\end{array}$ \\
\hline Trichomonas infections & Metronidazole ${ }^{a, b}$ & $\begin{array}{l}\text { 500mg, four pills OR, single dose } \\
\text { (total dose: } 2 \mathrm{~g} \text { ) }\end{array}$ & $\begin{array}{l}15 \mathrm{mg} / \mathrm{kg} / \mathrm{day} \text {, divided in } 3 \text { doses } / \text { day, } \\
\text { for } 7 \text { days (maximum daily dose: } 2 \mathrm{~g} \text { ) }\end{array}$ \\
\hline
\end{tabular}

Source: adapted from the Clinical Protocol and Therapeutic Guidelines for Comprehensive Care for People with Sexually Transmitted Infections ${ }^{20}$.

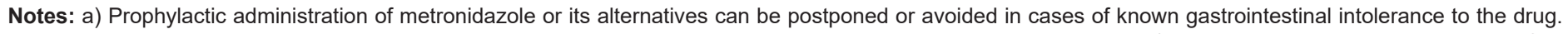

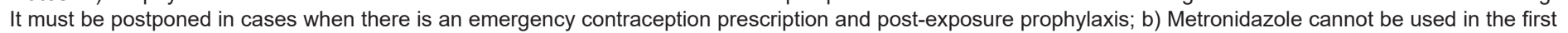
trimester of pregnancy.

FIGURE 1: Prophylactic regimen for non-viral sexually transmitted infections in sexual violence situations.

\begin{tabular}{|c|c|c|}
\hline Medication & Foreword & Dosage \\
\hline \multirow{2}{*}{ Tenofovir + Lamivudine } & $\begin{array}{c}\text { Coformulated pill (tenofovir 300mg + lamivudine } \\
300 \mathrm{mg})\end{array}$ & 1 pill oral route (OR) 1x/day \\
\cline { 2 - 3 } & $\begin{array}{c}\text { In case of lack of co-formulated Presentation: Pill } \\
\text { tenofovir 300mg + Pill lamivudine 150mg }\end{array}$ & $\begin{array}{c}\text { In case of lack of co-formulated Presentation: One } \\
\text { pill OR 1x/day + Two pills OR 1x/day }\end{array}$ \\
\hline Dolutegravir & Pill dolutegravir 50mg & One pill OR 1x/day \\
\hline
\end{tabular}

Source: adapted from the Clinical Protocol and Treatment Guidelines for Post-Exposure Prophylaxis of Risk of HIV, STI and Viral Hepatitis Infections ${ }^{15}$.

Note: a) Contraindication for people with acute renal insufficiency and during preconception care; or women of childbearing age, discard pregnancy and indicate regularly using efficient contraceptive; not recommended for people using phenytoin, phenobarbital, oxcarbazepine, carbamazepine, dofetilide, and pilsicainide.

FIGURE 2: Preferential antiretroviral presentation and dosage for post-exposure prophylaxis.

For pregnant women the preferred option for antiretroviral therapy regimen must be tenofovir and lamivudine, jointed with atazanavir/ritonavir in doses of atazanavir $300 \mathrm{mg}$ (one tablet) and ritonavir $100 \mathrm{mg}$ (one tablet), oral route, both once a day, or raltegravir in $400 \mathrm{mg}$ dose from the 14 th gestational week (one tablet, oral route, twice a day) ${ }^{18}$.

Breastfeeding women must be informed about the potential risks of transmission of HIV through breast milk ${ }^{28,29}$. In the context of sexual violence, the temporary interruption of breastfeeding should be advised. During the immunological window period, extracting and discard milk is recommended; once an HIV control test has been carried out in the 12th week after starting PEP and its result is non-reactive, breastfeeding reintroduction is authorized ${ }^{18}$.

In clinical practice, sexual abuse diagnosis in babies, children, and adolescents is complex, and it also depends on the health professional's awareness and sensitivity ${ }^{30}$. Behaviors that may indicate sexually abused children include sexual perpetration age-inappropriate way of playing, (such as repeatedly touching an adult's genitals or asking an adult to touch their genitals) $)^{30}$.

Despite such manifestations, evidence indicates that children's sexual violence remains invisible to health staff $^{31}$. Children are more vulnerable to STI due to the anatomical and physiological immaturity of their genital-anal mucosa, among other causes. The diagnosis of an STI in children can be the first sign of sexual abuse and must be investigated ${ }^{32,33}$. Most complaints are nonspecific; however, rectal or genital trauma or bleeding and STI not acquired in the perinatal period due to vertical transmission must draw the health professional's attention ${ }^{33}$.

Regimens and dosages of PEP for HIV for this age group must be adjusted, especially in children under $12^{15}$. For children over 12 , 
considering prescription safety and ease, tenofovir and lamivudine associated with dolutegravir are recommended ${ }^{18,34}$.

It should be noted that adolescents are entitled to PEP even without their parents or legal guardians' presence. In such cases, as provided for in the Child and Adolescent Statute - Act No. 8,069, of July 13, 1990 - the adolescent's discernment must be assessed, except in violent situations ${ }^{35}$.

If the person in a violent situation reports that they have not been vaccinated or have an incomplete vaccination schedule for hepatitis B, the first dose of the vaccine must be administered, or the vaccination schedule completed. Routine use of human antihepatitis B immunoglobulin (IGHAHB) is not recommended, unless the victim is susceptible and the person responsible for the violence is reactive to the hepatitis B virus surface antigen (HBsAg) or belongs to a risk group, such as, for example, people who use illicit drugs. When indicated, IGHAHB should be applied as early as possible, up to a maximum of 14 days after exposure ${ }^{18}$.

\section{PREGNANT PREVENTION IN SEXUAL VIOLENCE CONTEXTS}

Guidelines on preventing unintended pregnancy in women's victims under sexual violence care are available. For those deciding on this prophylaxis, levonorgestrel must be prescribed and offered in one $1.5 \mathrm{mg}$ tablet, oral route, or two $0.75 \mathrm{mg}$ tablets, single dose (or divided into two doses every 12 hours), up to five days after intercourse. This method has advantages in comparison with the Yuzpe method (administration of combined hormonal contraceptives as $200 \mathrm{mcg}$ of ethinylestradiol and $1 \mathrm{mg}$ of levonorgestrel in a single dose or divided into two doses, with an interval of 12 hours) ${ }^{36}$, given its greater effectiveness, since it fails in only $2 \%$ to $3 \%$ of cases, and safety, due to the lower occurrence of drug interactions and side effects ${ }^{36,37}$.

When sexual violence inevitably leads to pregnancy, abortion is permitted by Decree-Law No. 2,848, of December 7, 1940, article 128, item II of the Brazilian Criminal Code, and other non-legal rules ${ }^{8,38}$.

\section{SERVICE NETWORK ASSISTANCE AND ARTICULATION IN SEXUAL VIOLENCE SITUATIONS}

Assistance to people under sexual violence situations in (SUS) must be offered following the current technical standard by the Ministry of Health ${ }^{21}$. It must be carried out as per Act No. 12,845, of August 1, 2013 $3^{39}$ (provides for mandatory and comprehensive care by SUS), Decree No. 7,958, of March 13, 2013 (sets forth guidelines for assistance by Law Enforcement professionals and SUS), and art. 5 of Ordinance GM/MS No. 485, of April 1, 2014 (redefines the functioning of the service of assistance to people in such situation).

Health service, in general, can represent a privileged space for the identification of a people in situations of sexual violence, provided that the health professionals are sensitive and attentive to specific signs and symptoms presented during consultations. Once sexual that offers emergency, comprehensive and multidisciplinary care. In this type of consultation, the patient must be is welcomed by a multidisciplinary team for receiving medication and advice.
We highlight the role of listening and recording the violence event including clinical, gynecological, laboratory tests, evidence collection, emergency contraception, prevention for viral (HIV and hepatitis B) and non-viral STI, compulsory epidemiological notification in 24 hours (violence notification form), social, psychological and outpatient follow-up ${ }^{22,42}$.

Appropriate and quality care for victims of sexual violence demands structuring care networks with multidisciplinary teams, support at local level and implementation of protocols. Government agencies responsible for health and safety policies must identify the organizations and services available in the territory for this type assistance, such as: Women's Police Station, Child and Adolescent Police Station, Child Protection Council, Child, and Adolescent Rights Council, Reference Center for Social Assistance, Forensic Institute, Prosecution Office, shelters, women's groups, kindergartens, among others. Flow and access and case management problems at each level of this network need to be discussed and planned periodically ${ }^{43,44}$.

Even if the local level for comprehensive care of people affected by sexual violence, it is must be connected to neighboring cities for ensuring follow-up in specialized services ${ }^{7}$.

Figure 3 shows some essential steps for materializing care and social protection network (intersectoral or intersectoral), which do not necessarily follow a hierarchy and can happen concurrently. Services for the care of people under sexual violence situations must be registered in the National Registry of Health Establishments System (SCNES), under code $165^{44}$.

Health institutions must inform the availability of: (i) comprehensive care for people under sexual violence situations (classification 001 of specialized service 165), which can be organized in general hospitals and maternity hospitals, emergency services, Emergency Care Centers (UPA), and in the set of nonhospital emergency services, which must work 24 hours a day, and have a multidisciplinary team; (ii) outpatient care for people under sexual violence situation (classification 007 of specialized service 165); and (iii) pregnancy termination in the cases provided for by law (classification 006 of technical assistance 165) ${ }^{44}$.

Regarding assistance to people in sexual violence situation, compulsory notification stands out, as determined by Ordinance GM/MS No. 1,271, of June 6, 201445, and Ordinance GM/MS No. 204, of February 17, 2016 ${ }^{46}$, and the provisions of Act No. 8,069, of July 13, 1990 (provides for the Child and Adolescent Statute and other requirements) $^{35}$, in Act No. 10,778, of November 24, 2003 (establishes compulsory notification, in national territory, of the case of violence against women treated in public or private health services) $^{47}$, and Act No. 10,741, of October 1, 2003 (provides for the Elderly Statute and sets other measures $)^{48}$.

In case of sexual violence and suicide attempts, the notification must occur within 24 hours at the local level, aiming to ensure timely intervention in such cases ${ }^{45,46}$. Immediate record is essential for service organizations and provides timely access to the disease's prevention measures above. The notification shall take place from 


\begin{tabular}{|c|c|}
\hline \multirow{3}{*}{ Situation diagnosis } & $\begin{array}{l}\text { Mapping of governmental and non-governmental services working in } \\
\text { comprehensive care, in the promotion, defense, and protection of people's } \\
\text { rights in the territory, including assistance to the perpetrator of the aggression. }\end{array}$ \\
\hline & $\begin{array}{l}\text { Identification of "reception" services for comprehensive care for people under } \\
\text { violent situations. }\end{array}$ \\
\hline & $\begin{array}{l}\text { Service protocols and flows; articulation in intrasectoral and intersectoral } \\
\text { networks; type of service provided; address, telephone, e-mail, opening hours. }\end{array}$ \\
\hline \multirow{3}{*}{ Social mobilization and advocacy } & $\begin{array}{l}\text { Agreement with local management on the care and social protection network for } \\
\text { comprehensive care for people in a violent situation. }\end{array}$ \\
\hline & Normative enactment formalization. \\
\hline & $\begin{array}{l}\text { Strategic alliances with Child Protection and Rights Councils; Specialized } \\
\text { Reference Center for Social Assistance (CREA); Reference Center for Social } \\
\text { Assistance (CRAS); community associations; media; Prosecution Office, Law } \\
\text { Enforcement; Legislative and Judicial Branches. }\end{array}$ \\
\hline \multirow{3}{*}{ Permanent education } & $\begin{array}{l}\text { Awareness and training of health professionals at the three levels of care for } \\
\text { reception, service, notification, and follow-up cases. }\end{array}$ \\
\hline & $\begin{array}{l}\text { Articulation with services for promoting, protecting, and defending people's } \\
\text { rights in violent situations for comprehensive health care in continuing education. }\end{array}$ \\
\hline & $\begin{array}{l}\text { Articulate with teaching and research institutions for adding violence prevention } \\
\text { theme and promotion of peace culture in the courses of health, social assistance, } \\
\text { and education programs. }\end{array}$ \\
\hline \multirow{6}{*}{ Planning and management } & $\begin{array}{l}\text { Creation of a board management group in the care and social protection } \\
\text { network for people in violent situations and their families to articulate, mobilize, } \\
\text { plan, monitor, and evaluate the network's actions. }\end{array}$ \\
\hline & $\begin{array}{l}\text { Planning of actions and strategies for comprehensive health care for people in } \\
\text { violent situations, based on the local reality. }\end{array}$ \\
\hline & Development/update of humanized reception and care protocols. \\
\hline & $\begin{array}{l}\text { Adopting follow-up strategies and technical and psychosocial support to health } \\
\text { teams that assist people in violent situations, and encouragement to the } \\
\text { intersectoral network so that it also follows these strategies. }\end{array}$ \\
\hline & $\begin{array}{l}\text { Implementation of the 'Viva Contínuo' violence and accident surveillance } \\
\text { system in the Notifiable Diseases Information System (Sinan). }\end{array}$ \\
\hline & $\begin{array}{l}\text { Communication and dissemination to society of the list of services, with full } \\
\text { address and opening hours for people in violent situations (Service Guide). }\end{array}$ \\
\hline
\end{tabular}

Source: Clinical Protocol and Therapeutic Guidelines for Comprehensive Care for People with Sexually Transmitted Infections ${ }^{20}$.

FIGURE 3: Structure of the intrasectoral and intersectoral care and social protection network for people in sexual violence situation.

the flow defined by local surveillance: the health service fills out the specific form of the Notifiable Diseases Information System (Sinan) and forwards it to municipal surveillance, which follows the flow to the state surveillance and, later, to the Health Surveillance Department of the Ministry of Health ${ }^{45,46}$.

\section{ACKNOWLEDGMENTS}

The authors acknowledge this article's contribution by the members of the technical group of specialists responsible for developing the 2020 PDCT for Comprehensive Care for People with STI.

\section{AUTHORS' CONTRIBUTIONS}

Menezes MLB, Araújo MAL, Santos ASD, Gir E, and Bermúdez XPD contributed equally with the concept, design, draft, and critical review of the manuscript. All the authors approved the final version of the article, including the assurance of accuracy and integrity.

\section{ORCID}

Maria Luiza Bezerra Menezes - 0000-0001-7001-2005

Maria Alix Leite Araújo - 0000-0002-4156-5783

Adriano Santiago Dias dos Santos - 0000-0001-8514-1862

Elucir Gir - 0000-0002-3757-4900

Ximena Pamela Díaz Bermúdez - 0000-0002-3771-7684 


\section{REFERENCES}

1. Brasil. Ministério da Saúde. Portaria n ${ }^{\circ} 42$, de 05 de outubro de 2018 Torna pública a decisão de aprovar o Protocolo Clínico e Diretrizes Terapêuticas para Atenção Integral às Pessoas com Infecções Sexualmente Transmissíveis (IST), no âmbito do Sistema Único de Saúde - SUS [Internet]. Diário Oficial da União, Brasília (DF), 2018 Oct 8 [cited 2020 Cot 26]:Seção I:88. Available from: http://bvsms.saude. gov.br/bvs/saudelegis/sctie/2018/prt0042_08_10_2018.html

2. World Health Organization - WHO, Etienne GK, Linda LD, James AM, Anthony BZ, Rafael L. World report on violence and health, 2002. Sexual violence (Chapter 6). World report on violence and health [Internet]. Geneva: WHO; 2002 [cited 2020 Oct 26]. Available from: www.who.int/violence_injury_prevention/violence/global_campaign/ en/chap6.pdf

3. Lutgendorf MA. Intimate partner violence and women's health. Obstet Gynecol [Internet]. 2019 Sep [cited 2020 Oct 26];134(3):470-80. Available from: https://doi.org/10.1097/aog.0000000000003326

4. Tyson V. Understanding the personal impact of sexual violence and assault. J Women Politics Policy [Internet]. 2019 Mar [cited 2020 Oct 26];40(1):174-83. Available from: https://doi.org/10.1080/155447 7X.2019.1565456

5. Gomes R, Murta D, Facchini R, Meneghel SN. Gênero, direitos sexuais e suas implicações na saúde. Ciênc Saúde Coletiva [Internet]. 2018 Jun [cited 2020 Sep 14];23(6):1997-2006. Available from: http://dx.doi. org/10.1590/1413-81232018236.04872018

6. Fórum Brasileiro de Segurança Pública. Anuário brasileiro de segurança pública 2019 [Internet]. [São Paulo]: Fórum Brasileiro de Segurança Pública; 2019 [cited 2020 Jul 23]. 218 p. Available from: https://www. forumseguranca.org.br/wp-content/uploads/2019/10/Anuario-2019FINAL 21.10.19.pdf

7. Ministério da Saúde(BR). Ministério da Justiça (BR). Secretaria de Políticas para as Mulheres. Atenção humanizada às pessoas em situação de violência sexual com registro de informações e coleta de vestígios: norma técnica [Internet]. Brasília: Ministério da Saúde; 2015 [cited 2020 Oct 26]. Available from: https://bvsms.saude.gov.br/bvs/publicacoes/ atencao_humanizada_pessoas_violencia_sexual_norma_tecnica.pdf

8. Brasil. Presidência da República. Decreto-Lei $n^{\circ} 2.848$, de 7 de dezembro de 1940. Código Penal [Internet]. Diário Oficial da União, Rio de Janeiro (RJ), 1940 Dec 31 [cited 2020 Jun 24];Seção 1:4. Available from: https://www.planalto.gov.br/ccivil_03/decreto-lei/del2848.htm

9. Ministério da Saúde (BR). Secretaria de Vigilância em Saúde. Violências contra mulheres: análise das notificações realizadas no setor saúde, Brasil, 2011-2018. Bol Epidemiol [Internet]. 2019 out [cited 2020 Oct 26];50(3). Available from: https://antigo.saude.gov.br/images/pdf/2019/ novembro/07/Boletim-epidemiologico-SVS-30.pdf

10. Sabidó M, Kerr LR, Mota RS, Benzaken AS, Pinho AAP, Guimaraes $\mathrm{MDC}$, et al. Sexual violence against men who have sex with men in Brazil: a respondent-driven sampling survey. AIDS Behav [Internet]. 2015 Sep [cited 2020 Oct 26];19(9):1630-41. Available from: https://doi. org/10.1007/s10461-015-1016-Z

11. Zalewski M, Drumond P, Prügl E, Setern M. Sexual violence against men in global politics. New York: Routledge; 2018.

12. Drumond P. What about men? Towards a critical interrogation of sexual violence against men in global politics. Int Affairs [Internet]. 2019 Nov [cited 2020 Oct 26];95(6):1271-87. Available from: https://doi. org/10.1093/ia/iiz178

13. Chynoweth SK, Freccero J, Touquet H. Sexual violence against men and boys in conflict and forced displacement: implications for the health sector. Reprod Health Matters [Internet]. 2017 [cited 2020 Oct 26];25(51):90-4. Available from: https://doi.org/10.1080/09688080.2017.140189
14. Weare S, Porter J, Evans E. Forced-to-penetrate cases: lived experiences of men. Baseline Research Findings [Internet]. Lancaster: Lancaster University; 2017 [cited 2020 Oct 26]. 15 p. Available from: https:// wp.lancs.ac.uk/forced-to-penetrate-cases/files/2016/11/Project-ReportFinal.pdf

15. Bueno S, Pereira C, Neme C. A invisibilidade da violência sexual no Brasil. In: Fórum Brasileiro de Segurança Pública. Anuário brasileiro de segurança pública 2019 [Internet]. [São Paulo]: Fórum Brasileiro de Segurança Pública; 2019 [cited 2020 Jul 23]. p. 116-21. Available from: https://www.forumseguranca.org.br/wp-content/uploads/2019/10/ Anuario-2019-FINAL 21.10.19.pdf

16. Blondeel K, Vasconcelos S, García-Moreno C, Stephenson R, Temmerman M, Toskin I. Violence motivated by perception of sexual orientation and gender identity: a systematic review. Bull World Health Organ [Internet]. 2018 Jan [cited 2020 Oct 26];96(1):29-41. Available from: https://doi.org/10.2471/BLT.17.197251

17. Delziovo CR, Coelho EBS, d'Orsi E, Lindner SR. Violência sexual contra a mulher e o atendimento no setor saúde em Santa Catarina - Brasil. Ciênc Saúde Coletiva [Internet]. 2018 [cited 2020 Oct 26];23(5):1687-96. Available from: http://dx.doi.org/10.1590/1413-81232018235.20112016

18. Ministério da Saúde (BR). Secretaria de Vigilância em Saúde. Departamento de Vigilância, Prevenção e Controle das Infecções Sexualmente Transmissíveis, do HIV/ Aids e das Hepatites Virais. Protocolo clínico e diretrizes terapêuticas para profilaxia pós-exposição de risco (PEP) à infecção pelo HIV, IST e hepatites virais [Internet]. Brasília: Ministério da Saúde; 2018 [cited 2020 Oct 26]. Available from: http://www.aids.gov.br/pt-br/pub/2015/protocolo-clinico-e-diretrizesterapeuticas-para-profilaxia-pos-exposicao-pep-de-risco

19. Mascarenhas MDM, Tomaz GR, Meneses GMS, Rodrigues MTP, Pereira VOM, Corassa RB. Análise das notificações de violência por parceiro íntimo contra mulheres, Brasil, 2011-2017. Rev Bras Epidemiol [Internet]. $2020 \mathrm{Jul}$ [cited 2020 Oct 26];23(Suppl 01). Available from: https://doi.org/10.1590/1980-549720200007.supl.1

20. Casey EA, Masters NT, Querna K, Beadnell B, Hoppe MJ, Morrison $\mathrm{DM}$, et al. Patterns of intimate partner violence and sexual risk behavior among young heterosexually active men. J Sex Res [Internet]. 2016 [cited 2020 Oct 26];53(2):239-50. Available from: https://doi.org/10.10 $\underline{80 / 00224499.2014 .1002125}$

21. Bagwell-Gray ME. Women's healing journey from intimate partner violence: establishing positive sexuality. Qual Health Res [Internet]. 2019 May [cited 2020 Oct 26];29(6):779-95. Available from: https://doi. org/10.1177/1049732318804302

22. Ministério da Saúde (BR). Secretaria de Vigilância em Saúde. Departamento de Doenças de Condições Crônicas e Infecções Sexualmente Transmissíveis. Protocolo clínico e diretrizes terapêuticas para atenção integral às pessoas com infecções sexualmente transmissíveis (IST) [Internet]. Brasília: Ministério da Saúde; 2020 [cited 2020 Oct 26]. Available from: http://www.aids.gov.br/pt-br/pub/2015/protocolo-clinicoe-diretrizes-terapeuticas-para-atencao-integral-pessoas-com-infeccoes

23. Ministério da Saúde (BR). Secretaria de Atenção à Saúde. Departamento de Ações Programáticas Estratégicas. Prevenção e tratamento dos agravos resultantes da violência sexual contra mulheres e adolescentes: norma técnica [Internet]. 3. ed. Brasília: Ministério da Saúde; 2012 [cited 2020 Oct 26]. Available from: https://bvsms.saude.gov.br/bvs/ publicacoes/prevencao_agravo_violencia_sexual_mulheres_3ed.pdf

24. O'Byrne P, Orser L, Vandyk A. Immediate PrEP after PEP: results from an observational nurse-led PEP2PrEP study. J Int Assoc Provid AIDS Care [Internet]. 2020 Jan-Dec [cited 2020 Oct 26];19:2325958220939763. Available from: https://doi.org/10.1177/2325958220939763

25. Ministério da Saúde (BR). Secretaria de Vigilância em Saúde. Departamento de Vigilância, Prevenção e Controle das Infecções 
Sexualmente Transmissíveis, do HIV/Aids e das Hepatites Virais. Prevenção Combinada do HIV/Bases conceituais para profissionais, trabalhadores(as) e gestores(as) de saúde. Brasília: Ministério da Saúde; 2017 [cited 2020 Oct 26]. Available from: http://www.aids.gov.br/ pt-br/pub/2017/prevencao-combinada-do-hiv-bases-conceituais-paraprofissionais-trabalhadoresas-e-gestores

26. Centers for Disease Control and Prevention-CDC. updated guidelines for antiretroviral postexposure prophylaxis after sexual, injection drug use, or other nonoccupational exposure to HIV [Internet]. Atlanta: Centers for Disease Control and Prevention; 2016 [cited 2020 July 23]. 91 p. Available from: https://www.cdc.gov/HIV/pdf/programresources/ cdc-HIV-npep-guidelines.pdf

27. European AIDS Clinical Society. Guidelines: version 8.0 [Internet]. London: European AIDS Clinical Society; 2015 [cited 2020 July 23]. 94 p. Available from: https://www.eacsociety.org/files/guidelines_8_0english_web.pdf

28. Hurst SA, Appelgren KE, Kourtis AP. Prevention of mother-tochild transmission of HIV type 1: the role of neonatal and infant prophylaxis. Expert Rev Anti Infect Ther [Internet]. 2015 [cited 2020 Oct 26];13(2):169-81. Available from: https://doi.org/10.1586/14787210. $\underline{2015.999667}$

29. Bucher MK, Spatz DL. Ten-year systematic review of sexuality and breastfeeding in medicine, psychology, and gender studies. Nurs Womens Health [Internet]. 2019 [cited 2020 Oct 26];23(6):494-507. Available from: https://doi.org/10.1016/j.nwh.2019.09.006

30. Chiesa A, Goldson E. Child sexual abuse. Pediatr Rev [Internet]. 2017 [cited 2020 Oct 26];38(3):105-18. Available from: https://doi.org/10.1542/ pir.2016-0113

31. Vrolijk-Bosschaart TF, Brilleslijper-Kater SN, Benninga MA, Lindauer R, Teeuw AH. Clinical practice: recognizing child sexual abuse-what makes it so difficult? Eur J Pediatr [Internet]. 2018 [cited 2020 Oct 26];177(9):1343-50. Available from: https://doi.org/10.1007/s00431-0183193-Z

32. Adams JA, Farst KJ, Kellogg ND. Interpretation of medical findings in suspected child sexual abuse: an update for 2018. J Pediatr Adolesc Gynecol [Internet]. 2018 [cited 2020 Oct 26];31(3):225-31. Available from: https://doi.org/10.1016/j.jpag.2017.12.011

33. Rogstad KE, Wilkinson D, Robinson A. Sexually transmitted infections in children as a marker of child sexual abuse and direction of future research. Curr Opin Infect Dis [Internet]. 2016 [cited 2020 Oct 26];29(1):41-4. Available from: https://doi.org/10.1097/ QC0.0000000000000233

34. Ministério da Saúde (BR). Secretaria de Vigilância em Saúde. Departamento de Vigilância, Prevenção e Controle das Infecções Sexualmente Transmissíveis, do HIV/Aids e das Hepatites Virais. Protocolo clínico e diretrizes terapêuticas para manejo da infecção pelo HIV em crianças e adolescentes [Internet]. Brasília: Ministério da Saúde; 2018 [cited 2020 Oct 26]. Available from: http://www.aids. gov.br/pt-br/pub/2017/protocolo-clinico-e-diretrizes-terapeuticas-paramanejo-da-infeccao-pelo-hiv-em-criancas-e

35. Brasil. Casa Civil. Lei no 8.069, de 13 de julho de 1990. Dispõe sobre o Estatuto da Criança e do Adolescente e dá outras providências [Internet]. Diário Oficial da União, Brasília (DF), 1990 jul 13 [cited 2020 Jun 24] Seção 1:8. Available from: https://www.planalto.gov.br/ccivil_03/leis/ 18069.htm

36. World Health Organization - WHO. Fact sheet on the safety of levonorgestrel-alone emergency contraceptive pills (LNG ECPs) [Internet]. Geneve: World Health Organization; 2010 [cited 2020 July 23]. 3 p. Available from: https://apps.who.int/iris/bitstream/ handle/10665/70210/WHO_RHR_HRP_10.06_eng.pdf
37. Ministério da Saúde (BR). Secretaria de Atenção à Saúde. Departamento de Ações Programáticas Estratégicas. Anticoncepção de emergência: perguntas e respostas para profissionais de saúde [Internet]. Brasília: Ministério da Saúde; 2005 [cited 2020 Oct 26]. Available from: http://bvsms.saude.gov.br/bvs/publicacoes/caderno3_saude_mulher.pdf

38. Brasil. Ministério da Saúde. Portaria MS/GM n 2.561 , de 23 de setembro de 2020. Dispõe sobre o procedimento de justificação e autorização da interrupção da gravidez nos casos previstos em lei, no âmbito do Sistema Único de Saúde-SUS [Internet]. Diário Oficial da União, Brasília (DF), 2020 Sep 23 [cited 2020 Oct 14]; Seção 1:89. Available from: https://www.in.gov.br/en/web/dou/-/portaria-n-2.561-de-23-desetembro-de-2020-279185796

39. Brasil. Presidência da República. Casa Civil. Subchefia para Assuntos Jurídicos. Lei no 12.845 , de $1^{\circ}$ de agosto de 2013. Dispõe sobre o atendimento obrigatório e integral de pessoas em situação de violência sexual [Internet]. Diário Oficial da União, Brasília (DF), 2013 Aug 2 [cited 2020 Oct 26]. Available from: https://presrepublica.jusbrasil.com. br/legislacao/1035667/lei-12845-13

40. Brasil. Presidência da República. Casa Civil. Subchefia para Assuntos Jurídicos. Decreto 7958, de 13 de março de 13. Estabelece diretrizes para o atendimento às vítimas de violência sexual pelos profissionais de segurança pública e da rede de atendimento do Sistema Único de Saúde [Internet]. Diário Oficial da União, Brasília (DF), 2013 Mar 14 [cited 2020 Oct 26]. Available from: https://presrepublica.jusbrasil.com. br/legislacao/1034354/decreto-7958-13

41. Brasil. Ministério da Saúde. Portaria n $n^{\circ}$ 485, de $1^{\circ}$ de abril de 2014. Redefine o funcionamento do Serviço de Atenção às Pessoas em Situação de Violência Sexual no âmbito do Sistema Único de Saúde (SUS) [Internet]. Diário Oficial da União, Brasília (DF), 2014 Apr 1 [cited 2020 Jul 23];Seção 1:2. Available from: http://bvsms.saude.gov. br/bvs/saudelegis/gm/2014/prt0485_01_04_2014.html

42. Ministério da Saúde (BR). Secretaria de Atenção à Saúde. Departamento de Atenção Básica. Protocolos da atenção básica: saúde das mulheres [Internet]. Brasília: Ministério da Saúde; 2016 [cited 2020 Oct 26]. Available from: http://bvsms.saude.gov.br/bvs/publicacoes/protocolos atencao basica saude mulheres.pdf

43. Organização Mundial da Saúde - OMS. Relatório mundial sobre a prevenção da violência 2014 [Internet]. São Paulo: Organização Mundial da Saúde; 2020 [cited 2020 Jul 23]. 288 p. Available from: https://nev. prp.usp.br/wp-content/uploads/2015/11/1579-VIP-Main-report-PtBr-26-10-2015.pdf

44. Brasil. Ministério da Saúde. Portaria MS/GM n 618, de 18 de julho de 2014. Altera a tabela de serviços especializados do Sistema de Cadastro Nacional de Estabelecimentos de Saúde (SCNES) para o serviço 165 Atenção Integral à Saúde de Pessoas em Situação de Violência Sexual e dispõe sobre regras para seu cadastramento [Internet]. Diário Oficial da União, Brasília (DF), 2014 Jul 14 [cited 2020 Jul 23]; Seção 1. Available from: http://bvsms.saude.gov.br/bvs/saudelegis/sas/2014/ prt0618_18_07_2014.html

45. Brasil. Ministério da Saúde. Portaria MS/GM n ${ }^{\circ} 1.271$, de 6 de junho de 2014. Define a Lista Nacional de Notificação Compulsória de doenças, agravos e eventos de saúde pública nos serviços de saúde públicos e privados em todo o território nacional, nos termos do anexo, e dá outras providências [Internet]. Diário Oficial da União, Brasília (DF), 2014 Jun 6 [cited 2020 Jul 23];Seção 1. Available from: http://bvsms.saude.gov.br/ bvs/saudelegis/gm/2014/prt1271_06_06_2014.html

46. Brasil. Ministério da Saúde. Gabinete do Ministro. Portaria MS/GM n ${ }^{\circ}$ 204, de 17 de fevereiro de 2016. Define a Lista Nacional de Notificação Compulsória de doenças, agravos e eventos de saúde pública nos serviços de saúde públicos e privados em todo o território nacional, nos termos do anexo, e dá outras providências. [Internet]. Diário Oficial da União, Brasília (DF), 2016 Feb 18 [cited 2020 Sep 17]; Seção 1. Available from: 
http://saude.gov.br/images/pdf/2016/fevereiro/22/Portarias-204-e-205de-17-02-2016---Lista-Nacional-de-Notifica----o-Compuls--ria-e-ListaMonitoramento-Unidades-Sentinelas.pdf

47. Brasil. Presidência da República. Casa Civil. Subchefia para Assuntos Jurídicos. Lei $n^{0} 10.778$, de 24 de novembro de 2003. Estabelece a notificação compulsória, no território nacional, do caso de violência contra a mulher que for atendida em serviços de saúde públicos ou privados. Diário Oficial da União, Brasília (DF), 2003 Nov 25 [cited 2020 Oct 26]. Available from: http://www.planalto.gov.br/ccivil 03/ Leis/2003/L10.778.htm

48. Brasil. Presidência da República. Casa Civil. Subchefia para Assuntos Jurídicos. Lei $n^{\circ} 10.741$, de $1^{\circ}$ de outubro de 2003. Dispõe sobre o Estatuto do Idoso e dá outras providências [Internet]. Diário Oficial da União, Brasília (DF), 2003 Oct 3 [cited 2020 Oct 26]. Available from: http://www.planalto.gov.br/ccivil_03/LEIS/2003/L10.741.htm 